\title{
Church and State during the Reign of Emperor Constantin IV (668-685)
}

\section{Remus Mihai FERARU*}

Abstract: Church and State during the Reign of Emperor Constantine IV (668-665). Our study aims to present the measures taken by Emperor Constantine IV for meeting the objectives of his religious policy, and his efforts to reconcile the Church and the State. Constantine IV recanted his support of Monothelism, aiming to restore Orthodoxy. Simultaneously, he took steps towards reestablishing the relations between Constantinople and Rome. In 678, Constantine IV started negotiations aimed at reconciling the Church of Constantinople with the Church of Rome. These negotiations were materialized by his summoning of the 6th Ecumenical Council of Constantinople (680-681). The Emperor presided the Council; he took part in the first eleven sessions, as well as the concluding session thereof. The dogmatic definition of the Council denies Monothelism and confesses Diothelism and Dioenergism. Emperor Constantine IV regained his role as temporal ruler of the Church, as well as that of guarantor and defender of the true faith.

Keywords: Church, state, Emperor Constantine IV, 6th Ecumenical Council, Monothelism

In 662, Emperor Constans II (641-668) decided to move west. After a short stay in Rome, the Emperor headed to Syracuse,

${ }^{*} \mathrm{PhD}$, Assistant Professor, at the West University of Timisoara, Faculty of Letters, History and Theology, Department of Romanian Studies, Romania. 
in Sicily, where he established his residence (663) ${ }^{1}$. Constans II's relocation was explained by his will to reaffirm the unity of the Empire and organize a counterattack against the Arabs ${ }^{2}$. During the last years of his rule, Constans II supported Monothelism. His assassination in Syracuse $(668)^{3}$ put an end to the Monothelite crisis. Before his relocation (662), Constans II annexed his three sons - Constantine, Heraclius and Tiberius - to his regency.

After the death of Constans II (668), his oldest son, Constantine IV Pogonatos ("the Bearded") (668-685) was installed on the throne of Byzantium ${ }^{4}$. Since the start of his reign, Constantine IV was forced to share the power with his two brothers, Heraclius and Tiberius, whom he annexed to the throne as co-emperors (coimperatores). The new basileus even had to mint coins with the effigies of the three emperors ${ }^{5}$. He reestablished the Empire's capital at Constantinople.

1 Theophanes Confessor, Cronografia, translated from Greek, introductory study and notes by Mihai Țipău, Bucharest, Basilica Publishing House of the Romanian Patriarchy, 2012, 20.6.9., p. 338 (hereinafter cited as Cronografia).

${ }^{2}$ Jean Meyendorff, Unité de l'Empire et divisions des Chrétiens. L'Église de 450 à 680, traduction de l'anglais par Françoise Lhoest revue par l'auteur, Paris, Les Éditions du Cerf, 1993, p. 355.

3 Theophanes Confessor, Cronografia, 27.13.1., p. 341.

${ }^{4}$ Georgije Ostrogorski, Histoire de l'État byzantin, traduit de l'allemand par J. Gouillard, Paris, Payot, 1996, p. 154; Louis Bréhier, René Aigrain, Histoire de l'Église depuis les origines jusqu'à nos jours, vol. V: Grégoire le Grand, les États barbares et la conquête arabe (590-757), Paris, Bloud et Gay, 1938, p. 181.

${ }^{5}$ Michel le Syrien, Chronique, vol. II, éditée pour la première fois et traduite en français par J.- B. Chabot, Paris, Ernest Leroux Éditeur, 1901, XIII, p. 454 (hereinafter cited as Chronique); Gregory Abû'l-Faraj (Bar Hebraeus), Chronography, translated from Syriac by Ernest A. Wallis Budge, London, 1932, X: "And in the year nine hundred and eighty, one of the Greeks (A.D. 670) Constantinus commanded that the Rhomaye (Romania) should be subject to him and his brothers, Tiberius and Heraclius equally, that the effigies of the 
The evolution of the events in the Orient faced the Byzantine government with the need to revive its religious agenda. As its eastern provinces (Syria, Palestine and Egypt) had been taken over by the Arabs, forever lost to the Empire, Emperor Constantine IV understood that the Monothelite agenda of his predecessors lost its reason to exist. It was proven that Monothelism was not an efficient instrument of religious reconciliation with the eastern population - on the contrary, it had caused a series of malignant complications in the west, as well as the east ${ }^{6}$. That is why Constantine IV recanted his support of Monothelism, aiming to restore Orthodoxy. At the same time, he took steps towards reestablishing peace between Constantinople and Rome. Our study aims to present the measures taken by Emperor Constantine IV for meeting the two objectives of his religious agenda, and his efforts to reconcile the Church and the State.

\section{Constantine IV's Religious Policy in view of the Preparation of the 6-th Ecumenical Council}

When Constantine IV took the imperial throne, the relations between the Church of Constantinople and that of Rome were ambiguous. Patriarchs Thomas II (667-669), John V (November 669 - August 675) and Constantine I (September 2, 675 - August 9, 677) did not condemn the Typos decree of Emperor Constans II, while the Popes had taken a position of neutrality. Patriarch Constantine I's successor on the patriarchal see of Constantinople was Theodore I (August 677 - December 679). He asked Emperor Constantine IV to approve the erasure of Pope Vitalian's name from patriarchal

three of them should be [stamped] on the darics. And he warned every man not to make any distinction between them". https://archive.org/details/BarHebraeusChronography, (visited on 07.05.2016). ${ }^{6}$ G. Ostrogorski, op. cit., p. 158. 
diptychs, under the pretext that he had been a supporter of Monothelism. Theodore's request was granted by the Emperor ${ }^{7}$. In 678, after vanquishing the Arab's offensive against Constantinople, Emperor Constantine IV started taking steps for re-establishing relations with the Roman Church. The Basileus sent a letter (sacra) to Pope Donus (November 2676 April 11 678), which arrived to Rome after his death, being received by his successor, Pope Agathon (June 27, 678 January 10,681$)^{8}$. In this letter, the Emperor wrote that he had attempted to re-establish unity between Rome and Constantinople since the beginning of his reign, by summoning a general meeting $(\kappa \alpha \theta 0 \lambda l \kappa \dot{\eta} \sigma v v \alpha \dot{\theta} \theta \rho o l \sigma l \varsigma)$ of the two patriarchal sees ( $\theta \rho o ́ v o l)$, but that a series of unforeseen events prevented him from doing so.

He went on to say that he had already spoken with Patriarchs Theodore of Constantinople and Macarios of Antioch in order to find out what had been the reasons behind the division between Rome and Constantinople. He had learned that the dispute between the two sees was caused by the use of certain phrases that had not been used prior; they were introduced due to ignorance to the mysteries of faith, and that the two patriarchal

${ }^{7}$ Jan Louis van Dieten, Geschichte der Patriarchen von Sergios I. bis Johannes VI. (610-715), Amsterdam, Verlag Adolf M. Hakkert, 1972, p. 126; Ioan Marin Mălinaș, Dipticon sau Cronologie patriarhală și Imperială, vol. II/1: Biserica catholică Ortodoxă și patriarhii acesteia până în secolul al VIII-lea, Intre moștenirea Chalcedonului și încercarea de codificare a dreptului canonic prin Sinodul quinisext 691-692, Cluj-Napoca, Presa Universitară Clujeană Publishing House, 2009, p. 177, no. 310 b.

${ }^{8}$ Friedhelm Winkelmann, Die Quellen zur Erforschung des monoenergetischmonotheletischen Streites, în „Klio”, nr. 69, 1987, p. 547, nr. 156; cf. L. Bréhier, R. Aigrain, op. cit., vol. V, p. 184; F. X. Murphy, P. Sherwood, Constantinople II et Constantinople III, Paris, Éditions de l'Orante, 1974, p. 191. 
sees had not met in order to clarify this dogmatic matter ${ }^{9}$. The Emperor said that it would be a pity for such trivial issues to cause a permanent rupture between Rome and Constantinople.

Constantine IV also wrote that time does not allow for the unfolding of a general council, which is why his suggestion is for the two Churches to commence a series of negotiations in view of reconciliation. To this end, the Emperor asked the Pope to send to Constantinople a delegation comprised of at least three Papal emissaries, twelve bishops and archbishops selected from the patriarchy and one delegate from each Greek monastery in Rome. The Emperor ensured the Roman Pontiff that he would not use his authority in matters of faith; he also promised to welcome the Papal delegation with due respect. If no consensus would be reached, he promised he would send the delegates back to Rome in peace ${ }^{10}$.

Constantine IV's initiative was received with surprise and excitement in Rome. Regardless of the Emperor's position regarding the Monothelite dispute, it was obvious that he was aware of the need for religious peace in the Empire.

Before sending a delegation to the imperial capital in order to commence negotiations with the Church of Constantinople, as suggested by Constantine IV, Pope Agathon consulted all western bishops on the matter. For this purpose, he summoned a Council in Milan. The decisions of this Council were sent directly to the Emperor. Another Council was held at Heathfield, in England (680). They confessed to the Orthodox faith. The members of the Council proclaimed their adhesion to the decisions of the five

${ }^{9}$ I. M. Mălinaș, op. cit., vol. II/1, p. 177, regest nr. 310 a; Charles Joseph Hefele, Histoire des conciles d'après les documents originaux, vol. III/1, trad. par Dom. H. Leclercq, Paris, Éds. Letouzey et Ané, 1909, p. 473.

${ }^{10} \mathrm{Ibid}$., vol. II/2, p. 114, regest nr. 242; Ch. J. Hefele, op. cit., vol. III/1, pp. 473-474. 
Ecumenical Councils and to those of the Lateran Council. They also condemned Monothelism ${ }^{11}$.

The answers of the provincial councils reached Rome on March 25, 680. In view of researching these responses and sending Constantinople the final, common answer of the western bishopric, Pope Agathon summoned a Council in Rome in March 680, which was attended by 125 bishops from Gallia, England and Lombard Italy ${ }^{12}$. They drafted a confession of faith that condemned Monothelism in the spirit of the Lateran Council ${ }^{13}$.

It was only at the end of March 680 when Pope Agathon sent a letter to the Emperor in which he appointed the delegates requested by Constantine IV for the meeting in Constantinople ${ }^{14}$. In his answer to the Byzantine basileus, Agathon praised the Popes who had defended Orthodoxy; the Roman Pontiff gave Martin I as an example of a Pope "of apostolic remembrance". Similarly to Pope Honorius, he denounced "the pompous emptiness of words, these subtleties that give rise to heresies, while it is the holy knowledge, defined by saints and by his apostolic predecessors, as well as by the five Ecumenical Councils, that represents the foundation of the entire faith"15.

${ }^{11}$ Ch. J. Hefele, op. cit., vol. III/1, pp. 475-476.

${ }^{12}$ Cf. L. Bréhier, R. Aigrain, op. cit., vol. V, p. 185, who states that the meeting summoned in Rome by Pope Agathon in March 680 was not a council per se, but rather a theological conference.

13 Viorel Ioniță, Sinodul al VI-lea Ecumenic și importanța sa pentru ecumenismul actual, in „Studii Teologice”, XXX, (1978), no. 5-8, p. 418; see also Ch. J. Hefele, op. cit., vol. III/1, p. 474.

14 Joannes Dominicus Mansi, Sacrorum conciliorum nova et amplissima collectio, vol. XI, Graz-Austria, Akademische Druck-U. Verlagsanstalt, 1960-1961, col. 234 (hereinafter cited as Mansi).

15 Gilbert Dagron, Pierre Riché, André Vauchez (coord.), Histoire du Christianisme des origines à nos jours, vol. IV: Évêques, moines et empereurs (610-1054), Paris, Desclée, 1993, p. 644. 
The delegation appointed to take part in the meeting of Constantinople received two letters that they were to give the Emperor: one from the Pope and the other, from the Roman Council; the second letter included the confession of faith of the Roman Council, signed by the Pope and by the 125 bishops representing the provinces under the jurisdiction of the papal see. Both letters sent to the emperor were dated March $27680^{16}$.

In 679, Patriarch Theodore - who had stated anti-Roman convictions openly - was deposed by the Emperor. In his place, another Patriarch of Constantinople was elected - George I (December 679 - February 686) - who supervised the works of the 6th Ecumenical Council ${ }^{17}$.

\section{Constantine IV's Involvement in the Sessions of the 6- th Ecumenical Council}

The Roman delegation arrived in Constantinople at the beginning of September 680. They handed the Emperor the two letters from Pope Agathon and from the Council of Rome of 680, respectively. On the same day when he received the Pope's response (September 10, 680), Emperor Constantine IV issued an imperial decree (sacra) addressed to Patriarch George I of Constantinople, ordering him to summon all archbishops and bishops under his jurisdiction at Constantinople, in view of conducting a detailed research of the dogma concerning the wills

${ }^{16}$ Heinrich Denzinger, Enchiridion symbolorum definitionum et declarationum de rebus fidei et morum, Verbessert, erweitert, ins Deutsche übertragen und unter Mitarbeit von Helmut Hoping heraugegeben von Peter Hünermann, 39. Auflage, Herder, Freiburg im Breisgau, Basel, Rom, Wien, 2001, pp. 250-255; F. Winkelmann, art. cit., pp. 547-548, nr. 157, 158; L. Bréhier, R. Aigrain, op. cit., vol. V, p. 185; F. X. Murphy, P. Sherwood, op. cit., pp. 192-194.

${ }^{17}$ F. X. Murphy, P. Sherwood, op. cit., p. 193; L. Bréhier, R. Aigrain, op. cit., vol. V, p. 185. 
and energies into Christ. Also, Patriarch George I was to communicate the provisions of the imperial decree to Patriarch Macarios of Antioch; in his turn, he was ordered to summon the archbishops and bishops under his jurisdiction to take part in the Council held in the capital city ${ }^{18}$.

The theological conference originally called by the Emperor was declared an Ecumenical Council from the first session, whose works started on November 7 680. The members of the Council met in the domed hall of the "divine palace",

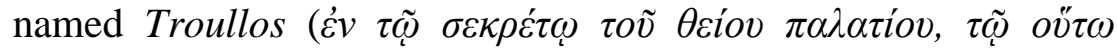
$\lambda \varepsilon \gamma o \mu \varepsilon \dot{v} \omega T \rho o v \lambda \lambda \omega)^{19}$. Because of the name of the hall where the sessions were held, the Council is also known as the Council in Trullo or the 1-st Council in Trullo - in order to be distinguished from the 2-nd Council in Trullo, probably held in the same hall in 691/692. The 2-nd Council in Trullo was also named the Quinisext Council ("the fifth, the sixth") because it completed the canonic work of the 5th and 6th Ecumenical Councils.

The 6-th Ecumenical Council was comprised of 18 sessions and lasted until September 16 681. The Council was presided by Emperor Constantine IV himself, who took part in the first 11 working sessions. At the end of the 11-th session, the Emperor said that the affairs of the state prevented him from taking part in the remaining sessions. For that reason, he delegated noblemen Constantine and Athanasios, as well as consuls Polyeucte and Peter, to preside the following sessions ${ }^{20}$. He returned to the last session of the Council, when the confession of faith was read ${ }^{21}$.

${ }^{18}$ Mansi XI, col. 201-204; I. M. Mălinaș, op. cit., vol. II/2, p. 115, regest nr. 244; F. Winkelmann, art. cit., p. 548, nr. 159; Ch. J. Hefele, op. cit., vol. III/1, pp. 483-484.

${ }^{19}$ Ibid., col. 166: "in basilica quae Trullus appellatur, intra palatium”.

${ }^{20}$ Ch. J. Hefele, op. cit., vol. III/1, pp. 499-500.

${ }^{21}$ Ibid., p. 486; J. Meyendorff, op. cit., p. 391. 
The summoning of the Council and the presiding thereof by Constantine IV is indicative of his intention to take direct control in its works. Thus, the Emperor manifested his will to exercise his prerogatives of defender of faith and protector of the Church. Moreover, hosting the works of the Ecumenical Council at the imperial palace showcases the Emperor's prominent role in its debates. The Emperor's status as "Christ's representative on Earth" and the sacred origin of the imperial power granted the secular space of the imperial palace a sacred nature. Therefore, the fact that a Holy and Ecumenical Council would take place at the imperial palace was fully legitimate ${ }^{22}$.

The seating of the participants was communicated at the beginning of the first session. The Emperor sat facing the members, surrounded by his high officials. In front of the Emperor, at the center of the hall, on a tetrapod, lay the Holy Gospel. To the left of the Emperor - which was considered the honorable seat - sat the representatives of the Pope and the Roman Council. Next to them sat Priest Theodore of Ravenna (the deputy of Archbishop Theodore of Ravenna), Bishop Basil of Gortyna in Crete (who was part of the Roman patriarchate), Hieromonarch George (representative of the Patriarchy of Jerusalem) and the Bishops of Thessaloniki, Athens and Corinth, under the jurisdiction of the Papal see. To the right of the Emperor sat Patriarchs George of Constantinople and Macarios of Antioch, Hieromonarch Peter - representative of the Patriarchy of Alexandria - and all the bishops under the jurisdiction of the Patriarchies of Constantinople and Antioch ${ }^{23}$. Notaries public, who had the task of reading the documents, were seated at the

22 Daniel Larison, Return to Authority: The Monothelete Controversy and the Role of Text, Emperor and Council in the Sixth Ecumenical Council, Chicago, 2009, pp. 184-185.

${ }^{23}$ Ch. J. Hefele, op. cit., vol. III/1, p. 486. 
open extremity of this horseshoe-shaped gathering. This arrangement was based on the Fathers' doctrinary opinions regarding the wills and energies of Christ, the reason why the Emperor had summoned the Council in the first place ${ }^{24}$. According to protocol, all those who took the floor spoke to the Emperor or his representatives. Thus, the Emperor, seated at the center of the gathering - just as Constantine the Great at Nicaea was presiding and leading the debates of the Council ${ }^{25}$.

Moreover, the Emperor and the imperial officers established the Council's working procedures and reviewed the texts used by both "sides": the Orthodox and the Monothelite. The Emperor's position at the center of the Council is suggestive of his neutrality and equidistance from both parties, which is also reflected in the contents of the documents issued ${ }^{26}$. In spite of the active involvement of the Emperor and his representatives in the debates, the final decisions on matters of church doctrine and discipline were taken exclusively by the members of the Council. For instance, during the 12-th session of the Council (March 22, 681), the Emperor's representatives asked whether Macarios could be reinstated as patriarch ${ }^{27}$ if he were to be imprisoned. The members of the Council debated, and their answer was negative. Suffragan Bishops of the Patriarchy of Antioch decided to address a petition to the Emperor, requesting the election of another Patriarch in the place of Macarios, who had been revoked

${ }^{24}$ F. X. Murphy, P. Sherwood, op. cit., p. 195.

${ }^{25}$ Ibid..

${ }^{26}$ D. Larison, op. cit., p. 185; F. X. Murphy, P. Sherwood, op. cit., p. 195.

${ }^{27}$ During the 9-th session of the Council (March 8 681), Patriarch Macarios of Antioch had been revoked from the patriarchal see and excommunicated as a heretic by the members of the Council. Macarios was a supporter of Monothelism. During the 7th session (March 7 681), Patriarch Macarios had presented a Monothelite confession of faith, see Mansi XI, col. 349357; F. Winkelmann, art. cit., p. 549, no. 163. 
and excommunicated by the council ${ }^{28}$. Also, in the conclusion of the 12-th session, Emperor's representatives requested the members of the Council to make a decision during the following session in regards to Patriarchs Sergius of Constantinople, Sophronius of Jerusalem, and to Pope Honorius ${ }^{29}$.

The members of the Council referred to the working documents of the Councils of Chalcedon (451) and Constantinople (553). They examined the confessions of the Church Fathers, often working with forged or truncated texts. For using documents drawn up during prior Councils, the 6th Ecumenical Council was dubbed "the council of registrars and librarians"; the members of the Council were helped by a large number of registrars and librarians who provided the documents for research ${ }^{30}$. The legal nature of the Council reflects the secular authority of the Emperor, who authorized and approved council debates. On the other hand, the liturgical nature of the council is indicative of the Emperor's role as defender of the faith. "The Emperor's procession holding the Holy Gospel through the middle of the domed hall is evocative of the priest's walk through the church during Holy Mass, which makes the Emperor a direct actor in the celebration of the liturgical act, rather than a mere bystander",31.

\section{The Re-Establishment of the Symphonia between Church and State; the Restoration of Religious Peace in the Empire}

The eighteen sessions of the Council were dedicated exclusively to debating the Monothelite heresy. In the last session of

28 F. X. Murphy, P. Sherwood, op. cit., pp. 206-207; L. Bréhier, R. Aigrain, op. cit., vol. V, pp. 188-189.

${ }^{29}$ Ch. J. Hefele, op. cit., vol. III/1, p. 501.

${ }^{30}$ Bernard Sesboüé, Joseph Wolinski, Histoire des dogmes, vol. I: Le Dieu du salut, Paris, Desclée, 1994, p. 438.

${ }^{31}$ Daniel Larison, op. cit., p. 186. 
the Council (September 16, 681), the confession of faith was read and signed by 174 bishops and delegates, as well as the Emperor. The works of the 18-th sessions were presided by Constantine IV himself; the Emperor also led the theological discussions of this solemn meeting. The dogmatic definition of the Council denies Monothelism and confesses Diothelism and Dioenergism. The basileus was acclaimed by the members of the Council as the guarantor and interpreter of the true faith: "Long live the Emperor! May you keep the light of the world alive! To Constantine, the new Marcian, may he be forever remembered! To Constantine, the new Justinian, may he be forever remembered! You dissipated heretics!"'32.

According to tradition, the Council's decisions were included in an imperial edict published on September 16, 681 and addressed to the citizens of Constantinople. The edict was displayed in the narthex of Hagia Sophia cathedral. It includes the confession of faith ruled by the Council comprised of the 174 Church Fathers: "... in Jesus Christ there are two wills and two activities or energies, corresponding to the two natures, unmixed and unchanged, without confusion and without separation, as well as unopposed, the human will and work following the divine entirely"33. The Emperor ordered that "no one dare to establish a different faith, or confess the doctrine about a single will and a single energy ... "34.

At the end of the 681 Edict of Faith, Constantine IV describes a complete "expression" of the intimate relationship between Emperor and Church. The Emperor is an embodiment of the Logos; he is Christ's representative on earth. The

${ }^{32}$ Mansi XI, col. 656.

33 Ioan Rămureanu, Milan Șesan, Teodor Bodogae, Istoria Bisericească Universală, vol. I (1-1054), Bucharest, Institutul Biblic și de Misiune al Bisericii Ortodoxe Române Publishing House, 1987, p. 394.

${ }^{34}$ Mansi XI, col. 697-700; I. M. Mălinaş, op. cit., vol. II/2, pp. 115-116, regest nr. 245; F. Winkelmann, art. cit., p. 549, nr. 165; L. Bréhier, R. Aigrain, op. cit, vol. V, p. 190; Ch. J. Hefele, op. cit., vol. III/1, pp. 512-513. 
basileus rules the earthly kingdom together with Messiah; he is a "co-emperor (symbasileus) of Christ the Emperor". After admitting that the theory behind the Christian faith is based on the works of the Apostles, Councils and Church Fathers, the Emperor stated that he lives and rules in this faith. In other words, his Christian life and the exercise of his imperial powers are founded on one and the same faith. Also, his rule of the earthly kingdom as eschatological consequences. For the Emperor, ruling together with Christ meant reaching the Kingdom of Heaven. The basileus hoped that this "partnership" would lead to an eternal rule, together with Christ, in the Kingdom of Heaven ${ }^{35}$. On December 23 681, Constantine IV issued another edict for all dioceses within the Empire, to celebrate the restoration of peace ${ }^{36}$.

\section{Emperor Constantine IV and the Church of Rome (681-685)}

A letter to Pope Agathon was drafted on behalf of the Emperor and the Council. It stipulated all the decisions taken at the 6th Ecumenical Council. Yet the news of Pope Agathon's death (January 10, 681) reached Constantinople before his diplomats left the imperial capital. Learning about Pope Agathon's death, the Emperor handed Roman diplomats a letter addressed to his successor, Leon II (682-683). In this letter, the Emperor recounted the entire history of Monothelism, as well as the works of the 6-th Ecumenical Council. Emperor Constantine IV showed that all members of the Council adhered to Pope Agathon's dogmatic letter, with the exception of Macarius of Antioch and his followers, who were dismissed from their positions and excommunicated. Macarius and the dismissed

${ }^{35}$ F. X. Murphy, P. Sherwood, op. cit., pp. 321-322.

${ }^{36}$ Mansi XI, col. 727-729; I. M. Mălinaş, op. cit., vol. II/2, p. 117, regest nr. 248; vezi și L. Bréhier, R. Aigrain, op. cit, vol. V, p. 190. 
bishops requested to be sent to Rome and be tried by the Pope, which the Emperor accepted. He asked Pope Leon to settle the matter. Also, the Emperor asked the Pope to send an apocrisiary to Constantinople, which would mean an official renewal of the diplomatic relations between the Church of Rome and that of Constantinople ${ }^{37}$.

Although elected Pope in December 681, Leon II was only ordained on August 17, 682. In September-October 682, the Roman Pontiff sent the Emperor a response letter approving the working documents of the 6-th Ecumenical Council. At the same time, Leon II cast an anathema over all heretics, including the authors of Monothelism and Pope Honorius $\mathrm{I}^{38}$, about whom he said that "he failed to preach the traditional teachings of the Apostles of his Church, but instead tainted his faith by improper teachings"39. The Pope approved the working documents of the 6-th Ecumenical Council and requested that they be translated into Latin; he then sent them to western bishops, ordering them to accept the Council's decisions and adhere to them ${ }^{40}$.

Until his death in 685, Emperor Constantine IV maintained very good relations with the Papal See. In 681, the Emperor decreased the taxes paid to the imperial tax authority by the Roman Churches in Sicily and Calabria. Moreover, on

${ }^{37}$ I. M. Mălinaș, op. cit., vol. II/2, pp. 116-117, regest nr. 247; F. Winkelmann, art. cit., p. 550, nr. 166; Ch. J. Hefele, op. cit., vol. III/1, pp. 513-514.

${ }^{38}$ Mansi XI, col. 725: "Pariterque anathematizamus novi erroris inventores, id est Theodorum Pharanitanum episcopum, Cyrum Alexandrinum, Sergium, Pyrrhum... necnon et Honorium"; see also H. Denzinger, op. cit. (Enchiridion ... ), p. 261; F. Winkelmann, art. cit., p. 550, no. 168.

${ }^{39}$ Ibid.: " ... et Honorium, qui hanc apostolicam Ecclesiam non apostolicae traditionis doctrina lustravit, sed profana proditione immaculatam fidem subvertere conatus est".

40 I. M. Mălinaş, op. cit., vol. II/2, p. 116, regest nr. 246; L. Bréhier, R. Aigrain, op. cit, vol. V, p. 191; Ch. J. Hefele, op. cit., vol. III/1, p. 515. 
certain occasions, he exempted church entities under papal jurisdiction from the obligation of selling grains at the prices established by imperial authorities ${ }^{41}$. By means of an edict issued in 682/683, Constantine IV rescinded the privileges of the Archbishop of Ravenna, whom he subjected directly to the Pope. Thus, the Archbishopric of Ravenna, which had been granted autocephaly status by Constantine II by means of an edict issued on March 1, 666 ${ }^{42}$, was reintegrated under the jurisdiction of the Papal See. The Emperor decided that the new Bishop of Ravenna would no longer be ordained by his suffragan bishops, but by the Pope ${ }^{43}$. By means of a new imperial edict issued in 684/685 and addressed to Pope Benedict II (648-685), to the clergy, people and army of Rome, the Emperor decided that the future pope would be ordained and enthroned immediately after his election, without having to be confirmed prior by the Emperor. The ratification of the Pope's election is entrusted to the Exarch of Ravenna, the main representative of the imperial power in Italy. Constantine IV sent the Pope locks of hair from his sons Justinian and Heraclius; this gesture was interpreted as a symbolic adoption of the two royal sons by Benedict II ${ }^{44}$.

${ }^{41}$ Liber Pontificalis, vol. I, texte, introduction et commentaire par L'Abbé L. Duchesne, Paris, Ernest Thorin Éditeur, 1886, LXXXIV, p. 366, r. 9-10: "necnon et alias divales iussiones relevans annonocapita patrimoniorum Siciliae et Calabriae non parva, sed et coemptum frumenti similiter vel alia diversa quae ecclesia Romana annue minime exurgebat persolvere".

${ }^{42}$ I. M. Mălinaș, op. cit., vol. II/2, p. 112, regest nr. 233.

${ }^{43}$ Ibid., p. 118, regest nr. 251.

${ }^{44}$ Ibid., regest nr. 252; vezi şi Charles Diehl, Études sur l'administration byzantine dans l'exarchat de Ravenne (568-751), (Bibliotheque des Écoles Françaises d'Athènes et de Rome, fascicule cinquante-troisième), Paris, Éd. Ernest Thorin, 1888, p. 369. 


\section{Conclusions}

For the first time since the rule of Emperor Heraclius, Constantine IV reestablished religious peace in the entire Christianity. By condemning Monothelism and restoring Orthodoxy, the Emperor fulfilled the main objective of his religious agenda, which later contributed to the instauration of religious peace in the Church and the re-establishment of the unity in the Eastern Church. Of equal importance, the Emperor succeeded to re-establish the relations between Rome and Constantinople. The Ecumenical Council of 681 brought the reconciliation between Church and state. Emperor Constantine IV regained his role as temporal ruler of the Church and defender of Orthodoxy.

\section{References}

1. Bréhier, Louis, Aigrain, René, Histoire de l'Église depuis les origines jusqu'à nos jours, vol. V: Grégoire le Grand, les États barbares et la conquête arabe (590-757), Paris, Bloud et Gay, 1938.

2. Dagron, Gilbert, Riché, Pierre, Vauchez, André, (coord.), Histoire du Christianisme des origines à nos jours, vol. IV: Évêques, moines et empereurs (610-1054), Paris, Desclée, 1993.

3. Denzinger, Heinrich, Enchiridion symbolorum definitionum et declarationum de rebus fidei et morum, Verbessert, erweitert, ins Deutsche übertragen und unter Mitarbeit von Helmut Hoping heraugegeben von Peter Hünermann, 39. Auflage, Herder, Freiburg im Breisgau, Basel, Rom, Wien, 2001.

4. Diehl, Charles, Études sur l'administration byzantine dans l'exarchat de Ravenne (568-751), (Bibliotheque des Écoles Françaises d'Athènes et de Rome, fascicule cinquantetroisième), Paris, Éd. Ernest Thorin, 1888. 
5. van Dieten, Jan Louis, Geschichte der Patriarchen von Sergios I. bis Johannes VI. (610-715), Amsterdam, Verlag Adolf M. Hakkert, 1972.

6. Gregory Abû'l-Faraj (Bar Hebraeus), Chronography, translated from Syriac by Ernest A. Wallis Budge, London, 1932 (https://archive.org/details/BarHebraeusChronography).

7. Hefele, Charles, Joseph, Histoire des conciles d'après les documents originaux, vol. III/1, trad. par Dom. H. Leclercq, Paris, Éds. Letouzey et Ané, 1909.

8. Ioniță, Viorel, Sinodul al VI-lea Ecumenic și importanța sa pentru ecumenismul actual, in „Studii Teologice”, XXX, (1978), no. 5-8, pp. 357-485.

9. Larison, Daniel, Return to Authority: The Monothelete Controversy and the Role of Text, Emperor and Council in the Sixth Ecumenical Council, Chicago, 2009.

10. Liber Pontificalis, vol. I, texte, introduction et commentaire par L'Abbé L. Duchesne, Paris, Ernest Thorin Éditeur, 1886.

11. Mansi, Joannes Dominicus, Sacrorum conciliorum nova et amplissima collectio, vol. XI, Graz-Austria, Akademische Druck-U. Verlagsanstalt, 1960-1961.

12. Mălinaș, Ioan Marin, Dipticon sau Cronologie patriarhală și Imperială, vol. II/1: Biserica catholică Ortodoxă şi patriarhii acesteia până în secolul al VIII-lea, Intre moștenirea Chalcedonului și încercarea de codificare a dreptului canonic prin Sinodul quinisext 691-692, Cluj-Napoca, Presa Universitară Clujeană Publishing House, 2009.

13. Meyendorff, Jean, Unité de l'Empire et divisions des Chrétiens. L'Église de 450 à 680, traduction de l'anglais par Françoise Lhoest revue par 1'auteur, Paris, Les Éditions du Cerf, 1993.

14. Michel le Syrien, Chronique, vol. II, éditée pour la première fois et traduite en français par J.- B. Chabot, Paris, Ernest Leroux Éditeur, 1901. 
15. Murphy, F. X., Sherwood, P., Constantinople II et Constantinople III, Paris, Éditions de l'Orante, 1974.

16. Ostrogorski, Georgije, Histoire de l'État byzantin, traduit de l'allemand par J. Gouillard, Paris, Payot, 1996.

17. Rămureanu, Ioan, Șesan, Milan, Bodogae, Teodor, Istoria Bisericească Universală, vol. I (1-1054), Bucharest, Institutul Biblic și de Misiune al Bisericii Ortodoxe Române Publishing House, 1987.

18. Sesboüé, Bernard, Wolinski, Joseph, Histoire des dogmes, vol. I: Le Dieu du salut, Paris, Desclée, 1994.

19. Saint Theophanes the Confessor, Cronografia, translated from Greek, introductory study and notes by Mihai Țipău, Bucharest, Basilica Publishing House of the Romanian Patriarchy, 2012.

20. Winkelmann, Friedhelm, Die Quellen zur Erforschung des monoenergetisch-monotheletischen Streites, in „Klio”, no. 69, 1987, pp. 515-559. 